\title{
DISCURSIVE GOVERNMENTAL AND MEDIA RESPONSE TO COVID-19: THE CASE OF SERBIA
}

\author{
SRĐAN MLADENOV JOVANOVIĆ ${ }^{1}$ \\ ${ }^{1}$ Nankai University, No.38 Tongyan Road, Jinnan District, Tianjin , P.R. China 300350. ORCID: 0000- \\ 0003-2612-4733, Email: smjovanovic@nankai.edu.cn
}

\begin{abstract}
Serbia's government, led by Aleksandar Vučić, has in scholarship been classified as semi-authoritarian, using Marina Ottaway's classification. Its media have also been described as being in heavy, biased support of the government. Scholarship has further revealed that the Vučić-led, post-2012 government, has thrown the country backwards in time, with corruption and affairs being the primary instance by which the regime can be described. Expectedly, the response of the government and the government-supporting media to the COVID-19 pandemic has been less than professional. The initial response included official government press conferences in which the novel coronavirus was deemed to be 'funny' and that, in the middle of the pandemic explosion and increased deathrate in Italy, Serbia's population was advised to go to Italy for 'shopping'. The media furthermore tried to pin the pandemic to Serbia's opposition alleged attempts to topple the government via 'coronavirus propaganda'. This article proposes to tackle the government's and their supporting media's responses to COVID-19 in February/March 2019 from a Discourse Analytical perspective.
\end{abstract} KEYWODDS: Serbia, Aleksandar Vučić, COVID-19, Discourse Analysis, coronavirus, pandemic 


\section{INTRODUCTION}

As of the moment of the writing of this paper, the COVID-19, somewhat unspecifically referred to as the "coronavirus", ${ }^{1}$ has ramped up over 700,000 cases and over 33,000 confirmed deaths globally. Since its outbreak in the Wuhan province of the People's Republic of China, it has spread globally and morphed into a pandemic, with Europe's Italy, Spain, and Germany becoming the new focus of the disease. With the global nature of the infection, and with the planet boasting somewhat over 200 sovereign states, the states' individual responses were bound to differ.

The Serbian government, led by PM-cum-president, Aleksandar Vučić, notorious for his warmongering during the 1990s and for being a high-ranking member of the government of Slobodan Milošević (the Minister of Information, 1998-99), has had a poor response to the looming epidemic within the country. There were official talks about COVID-10 being "the funniest virus ever" and that people should "go to shopping in Italy" while people were dying there due to the failing health system. To put the issue in perspective, the Serbian government was far from the only one in which politicians of the highest rank were guilty of malfeasance, having reacted either poorly, with lack of knowledge or preparation, or simply boasting preposterous claims. Brasil's Bolsonaro initially dismissed the virus as a "fantasy" and "trick", later claiming that he would "not feel anything" should he be infected (Phillips 2020); in the USA, “Trump has undermined his administration's own efforts to fight the coronavirus outbreak - resisting attempts to plan for worst-case scenarios, overturning a public-health plan upon request from political allies and repeating only the warnings that he chose to hear" (Diamond 2020); Boris Johnson "joked that the initiative to build more ventilators could be known as 'Operation Last Gasp'” (Paton 2020), after himself contracting the virus.

The situation begs for numerous analysis, from public health initiatives, via governance, to public policy, and many more. We have chosen to tackle the Serbian government's (and the government-supporting media's) response to the upcoming epidemic from the point of view of rhetoric. The questions we are asking, based on the investigation of discursive practices (Aydın-Düzgit 2016), are the following: How is the virus/pandemic named and referred to? What characteristics are attributed to it? How did the abovementioned changed over time? By means of what kind of argumentation is the rhetoric around COVID-19 presented? What metadiscursive elements figure as most relevant within the presented narrative?

Prior to the tackling of the discourse itself, it is of some necessity to present the socio-political context in which Serbia locates itself at the beginning of the third decade of the $20^{\text {th }}$ century.

\section{SERBIA IN CONTEXT}

Since the coming into power of the Serbian Progressive Party (Srpska napredna stran-

\footnotetext{
${ }^{1}$ Formally, the "coronavirus" designation refers to the whole family of coronaviridae, discovered already in 1965, the novel COVID-19 being the disease that the novel coronavirus causes.
} 
$k a$, progressive only in name) in 2012 and the consequent meteoric rise of Aleksandar Vučič, Serbia has seen deterioration in almost all fields of governance and socio-political life, from the economic, via public health, to a significant increase in corruption (Jovanović 2018b). Though tackled seldom within the contemporary academia, the works that have been produced on the topic of Vučićs Serbia have classified it as semi-authoritarian (Radeljić 2019), based on Marina Ottaway's theoretical assumptions (Ottaway 2013). V-Dem (v-dem.net) has but recently published their analyses on states that have seen the largest increase in their degrees of authoritarianism; together with Hungary, Turkey, Brasil, Poland, and India, Serbia has found its place at the top six fledgling autocratic regimes (Avakumović 2020).

Year by year after the fateful 2012 elections, Serbia has been increasingly plagued by an as of yet unending row of affairs produced by the very top of the government, some of them of a criminal nature, some of them simply peculiar, for the lack of other words (Jovanović 2018b). From the secretive destruction of parts of Belgrade in order to commence the building of the Belgrade Waterfront project (done under shady circumstances, with one person dying after having confronted masked thugs) that turned out to be a money-laundering fence for the sales of arms into the UAE (Đurđević 2019, N1 2019, Telesković 2019) to the invented attempts on the life of Aleksandar Vučić (Alo! 2017, Informer 2016), the concept of the affair became synonymous with his regime. Most notoriously, the Vučić regime became known for an almost utter deference to the Party, where high-ranking official positions, up to the level of the Minister, were relegated to people with poor or no skills whatsoever, or with people with criminal backgrounds. The Minister of Defense, Aleksandar Vulin, has never served in the army (N1 2017); the Minister of Health was known under the moniker „dr. Death“ due to his connections with criminal clans (Popović 2017). To hide its low productivity and poor success rate in urban development, the government was known to formally open elevators in the home for the elderly, with the cutting of the red cord (Leskovac and Špero 2015). All of these examples are barely even scratching the surface of the regime of Aleksandar Vučić.

Additionally, the freedom of the press, including the freedom of speech, have seen drastic diminishing during Vučićs reign, as testified by Freedom House (FreedomHouse 2016, Freedomhouse 2019). As it turned out, Vučić's regime was judged to draw vast amounts of power and influence through the government-supporting media, such as the tabloids Informer, Alo!, or the Pink television. Within these media, as research has shown, Vučić was and is presented as the savior of the country, an Ubermensch who is under constant attack by known and unknown forces (Jovanović 2018a). Similarly, the abovementioned government-supporting media have campaigned tirelessly to smear his opposition, presenting a narrative in which they are seen as drug addicts, maniacs, supporting of lynching, rape, and violence, and much more (Jovanović 2019). Vučić himself became known for continuously and iteratively appearing in the media (except the few free media that still exist), wherein he developed a specific style of speech, tackled by Nemanja Rujević of Deutsche Welle. Vučić, in his speech, commonly talks about himself, with dramatic breaks, sighs, occasional shouting, and a general dramatic tone to his messages; he criticizes those who oppose, with constant com- 
plaining (Rujević 2017).

Having in mind such a government led by such a person, the question poses itself: are the same discursive modi operandi used when tackling the COVID-19 pandemic? What are the characteristics of the COVID-19 discourse in 2020?

\section{GOVERNMENT AND MEDIA DISCOURSE}

As COVID-19 reached Europe, it was visibly obvious that Serbia had been woefully unprepared for the outbreak. On February 26, a press conference was held by the government, in which all the callousness and lack of competence surfaced for everybody to be seen. It was presented to the public that "complete preventive measures" have been taken "up to the tiniest of details", that there "would be no problems whatsoever", that the virus was "something much weaker than the common flu", and that "in two to three days, we are going to be completely prepared. Completely". There was furthermore "no reason for great concern". President Vučić opined that the Minister of Health told him that "medical alcohol kills the virus completely" and that he (Vučić) "found a reason to drink a shot per day". Serbia would not close its borders, and that everything would go on as normal, "people should go to stadiums normally, to halls, lead their lives normally” (Marković 2020b).

During the same press conference, another fairly new public figure emerged, one dr. Vladimir Nestorović, known formerly only as an antivaxxer, as well as a person who (sic!) claimed that blue and green-eyed people were aliens (TV 2019). He proclaimed, on behalf of the Government of the Republic of Serbia, that he "could not believe that the people who have lived through sanctions, bombing, all kinds of mistreatment, would be afraid of the funniest virus in the history of mankind ... I was against even ordering masks and tests. I think that would be entirely senseless, look, if we had no tests, we would not even know that there was an epidemic" (Marković 2020b:16). He further opined that "oestrogen definitely protects women ... they hardly even die from this virus. So, when it comes to women, feel free to go shopping in Italy, I hear they are going to have great discounts there”. While during the first part of his speech Vučić was smiling, at this point, he was laughing and visibly shaking.

The first answers to the research questions posed - how was the virus referred to - is by now already clear. A narrative was presented, strengthened by the fact that several pundits, including the president himself, were there no confirm it in officialdom, that the virus was "laughable", a "joke". In other words, the narrative was playing the gravity of the situation down, at the time when people in Italy were already dying and the Italian epidemic has reached horrendous levels, with triage leaving hexagenarians and the older to die (Parodi, Aloisi and Barbaglia 202). Entering somewhat in multimodal discourse analysis mode, here we have to include so called "behavioral processes" in discourse, ones that "refer to physiological and psychological behavior such as breathing, coughing, smiling, laughing, crying, staring, and dreaming, etc" (Wang 2010:255). This is in regard to the President first smiling, then laughing at the critical situation that he and his pundits presented discursively as jovial, funny, laughable. His visible fits of laughter further strengthened the presented jocund, convivial rhet- 
oric of the Republic of Serbia in its official announcement.

The discourse soon broke into chaotic bits and pieces, as the soon-to-be daily press conferences now presented random, incongruent bits of information. It was, namely, unknown how many respirators were available in the public health system. The Clinic for Infectious and Tropical Diseases in Belgrade, for instance, boasted a sum total of ten; a number that could not withstand even a percentage of the potentially ill (tens of thousands would be needed). As Marković reported, the Prime Minister, Ana Brnabić, first stated that their number was a state secret, even though it could by no means be such according to state law, after which Vučić proclaimed that he would be "to blame for not allowing it to be publicly known", as he said, he "wanted to present the figure as lower in order to be able to procure more"; admitting to deception and presenting himself in a positive light. He then opined that there was "1008 respirators" and that it should be "enough", after which he immediately said that he would be asking for 500 more, even though he said that the number present would suffice. Then he mentioned he was procuring them personally, in the "economic gray zone", and that that he managed to get " 50 more", "so you can shoot me when this is all over, I will not tell you how I got them". After that, he again stated that the number would in the future be a state secret (Marković 2020b). Vučić, furthermore, once having returned from a conference in New York where two people tested positive, refused to take the test, saying that the opposition wants him quarantined so that they could win the upcoming elections (Drčelić 2020).

There is much to unpack here. Due to the (even admitted) deception in public discourse by the highest levels of government, it would be wise to draw upon Galasinski's magnum opus about discourses of deception (Galasinski 2000), which underlines that the study has been conducted under the premises that the deception is intentional. Borrowing from Puzynina (Puzynina 1992), he defines deception as "an attempt to affect the target in such a way that her or his behavior/action is an instrument of attaining the goals of the manipulator, who acts without using force but in such a way that the target does not know the goal of the manipulator's action" (Galasinski 2000:21). Deceiving the public by presenting a hectic pastiche of contradictory evidence would go well in presenting the government as facing a tough adversary, which has so far figured heavily in the deception tactics used by the government-supporting media (Jovanović 2018c). Furthermore, and also in agreement with the deceptive tactics used before, this discursive strategy sends the message that Vučić himself is suffering in order to help his people; after all, he is personally procuring respirators by putting himself at risk for not going through official, state channels. Where the government omits necessary data is also tackled by Galasinski, who calls it deception by omission (Galasinski 2000:22). Together, the discourse presented can be best classified into the drawer of so-called "half-truths", that fall under the categories of "exaggeration, minimization, or equivocation” (Galasinski 2000:23), also classified as distortions (Galasinski 2000:42). At first, the narrative was minimized when the virus was presented as "laughable”. Direct deception was attempted when Vučić spoke that nobody called it such, after which equivocation took precedence when the press conferences started spewing out contradictory and confusing bits of information. As Galasinski 
noted, deceptive messages often include "inadvertent behaviors divulging the deceptive intent" (Galasinski 2000:27), thus the incongruous messages during the respirator-based press conference.

Where does that leave us with the third pillar of half-truths, exaggeration? As it turns out, it is within the realm of the rhetoric against the opposition, as well as the discourse of the government-supporting media. During the press conference, Vučić managed to accuse the opposition of "killing 137 people in 2009 during the swine flu epidemic" (Marković 2020b:18). Note the exaggeration: the opposition (that was in power in 2009) did not kill anybody; but some people did die during the swine flu season. Via the Speech-act of exaggeration, Vučić presented both the opposition in a bad light, as well as himself in a good one, being that he is the wall that stands between more people dying and the end of the pandemic. This is yet another type of discursive strategy of manipulation that Galasinski describes simply as "putting words out of context" (Galasinski 2000:38), which was done with the word "kill”. Vučić's plea to "be shot" for procuring "50 more", without telling the public how exactly that had been done, is congruous with him commonly taking the role of the victim; a trope that has figured constantly since his coming into power (Jovanović 2018a).

The tabloids known to have been showing unwavering support to the regime of Aleksandar Vučić have also contributed to the confusion by publishing untruths. Alo! Wondered if religious fasting could contribute to the strengthening of bodily immunity to help in the fight against the virus (Marić 2020), while the Informer chose to enter its specific brand of vitriol against the opposition, claiming that there was a "sick plan" of the opposition "to release lies about the corona ... to postpone the elections and topple Vučić?!” (Informer 2020b). This is a direct continuation of the vehement rhetoric against the opposition that is seen in tabloids such as the Informer or Alo!, who are known to have used many a means to smear the opposition, especially after the beginning of the late 2018 statewide protests against the Vučić regime (Jovanović 2019). The media further opined that the World Health Organization was "in deal with the pharmacomafia" to make "the coronavirus hoax of the century" (Marković 2020b).

It has been noted that "journalism is typically a discursive re-construction of reality" (Carvalho 2008:164). We are in need of adding a rather important caveat here, expanding the abovementioned claim into the realization that low-level journalism is (often, though not all the time) an attempt of a discursive re-construction of the perceptions of reality. When a tabloid claims that garlic is an effective means in fighting COVID-19, it does not create such a reality; garlic will not become a cure against the virus. What it in practice does is construct a perception of reality by the recipient - in this case, the believing audience - in which the recipient might believe that garlic is a cure.

After the initial press conference, it seemed that the gravity of the situation has reached the Vučić regime. The narrative changed completely, as now, instead of advising the public to go shopping in Italy, Vučić was imploring his auditorium to check in with the health services if they were in Milan. When confronted with the fact that his experts opined that the virus was "funny", he burst into anger: "I cannot stand this injustice, that people are attacking dr. Nestorović, attacking these people here who 
are serious and responsible. They say 'funniest virus'. Do not lie, nobody said this was the funniest virus" (Marković 2020b). What we need to have in mind here is that the initial press conference was held on the first channel of the Radio Television Serbia, the state's official network that can be seen in almost any household within the state, implying that it had heavy coverage and a large audience. The fact that the audience knew that the government presented the virus as the "funniest", coupled with the fact that now Vučić was accusing people who claim so of lying, is telling. A conjecture can be made - though not proven - that the President has reached such levels of callousness that not even standardized deception (by half-truths and spins) was no longer necessary. By feat and declaration, Vučić erased history. This was, to emphasize, done by declaration. In linguistics and semantics, declarative discourse is known to possess a so-called "assertoric force" (Jary 2011). According to Cicourel, "declarative systems of knowledge are viewed as advantageous because they are supposed to receive new knowledge without having to develop new rules of inference, yet these same rules make it possible to create new inferences" (Cicourel 1985), stemming from Rumelhart and Norman's investigation and inference that said rules are independent of fact (Rumelhart, Norman and Anderson 1981). There was an attempt of changing reality to suit the speaker, with presumed hope that the audience would comply.

As the discourse changed, the novel coronavirus suddenly became a dangerous issue. Vučić already on March 12 opined that "Serbia is in an exceptionally complicated situation", as it was hit by a "difficult disease and infection” (Marković 2020b). A state of emergency was declared, with martial law prohibiting anybody to go out first after 20:00, then after 17:00, with people over 65 under an almost total ban of movement, allowed only to go shopping between 04:00 and 10:00 in the morning. According to the journalist, Zora Drčelić, who has been reporting on the regime's malfeasance for years, "since Vučić made the story about the disease that is rummaging through all of the world serious, he has been scolding, begging and imploring citizens do have trust in the government, calling for unity and solidarity, whilst not binding himself to any of those" (Drčelić 2020).

The question why the virus would initially be presented as laughable leads to some conjecture. As it turned out, the vice-director of the Institute for Public Health "Milan Jovanović Batut”, Darija Kisić Tepavčević, proclaimed on national television, in a live session, that the first case of COVID-19 was registered on March 1, not on March 6, as was part of the official narrative (Danas 2020). What happened in the meantime was that on March 4, Aleksandar Vučić amassed tens of thousands of people to sign up for support for his electoral list, giving way to the conclusion that the first people who got infected were kept under the rug in order to garner electoral support for the April elections (Marković 2020a). Nevertheless, Kisić Tepavčević then doubled back, and said that she made an error when she said that the first case was isolated on March 1(Nedeljnik 2020a). It is impossible to conclude whether she really made an initial mistake, or if she was perhaps forced into claiming that she did. Be that as it may, scholarship has already established that "with very few exceptions, political elites use discourse to win a target audience without necessarily attending to one of the basic rules of a successful speech act - sincerity” (Balzacq 2005:176). 
That the initial press conference on which the virus was presented as a joke was problematic for the regime even after several weeks have passed was seen in the fact that parts of the public, by the time of the writing of this article, still have not let the issue go, prompting Vučić to keep defending his pundits by late March 2020:

It would be no problem for me to say that someone was wrong. I understand the political need of the question, I know many want to know, to see if anyone is guilty. Dr. Nestorović is a genius above all. He is extraordinary, it is important that people are told that we will fight. He never said for a second that we would not fight. Then I said that we were facing a serious crisis, a great responsibility. He wanted to encourage people, tell them not to be scared, no one made fun of it, and yes, he was optimistic because there were no deaths. We knew there would be a black scenario, and that's when we said it. I understand the need for people to always find the culprit. If that's the solution, it's my fault. We are the first to introduce a state of emergency, curfew, and I am proud of that, said Serbian President Aleksandar Vučić. (Alo 2020)

In the quote above, we see Vučić present the insistence on criticizing Nestorović as "political”, presenting his team as being under political attack, in order to evade the lack of professionalism and direct accusations leveled against them. The new exaggeration about the person who thinks blue-eyed people are aliens is that he is "extraordinary", a "genius", as in his narrative, Vučić is surrounded by high-level professionals. Setting the "funny" virus aside, the new, somber narrative was still present, as Serbia was facing a "serious crisis" and "great responsibility". Yet again painting a target on himself, he "confessed" that all of it was "his fault", yet it remained unclear what exactly was his fault. Evasion, exaggeration, presenting oneself as a victim: these are the crucial moments in Vučić's discourse that has been present in the public for years (Jovanović 2018a, Jovanović 2018c).

In order to even further stress the discursive continuity throughout the rule of Aleksandar Vučić, we need to emphasize the vigorous defense of dr. Nestorović. This is yet another common instance for President Vučić, who, in the past, defended his collaborators with equal vigor. When high-ranking members of his clique were receiving flak from the opposition due to a row of affairs, such as Minister Lončar, former Minister Gašić, or former Minister Stefanović, he never let them go, never administered punitive measures, and instead defended them in front of the public unwaveringly (Beta 2020, Tanjug 2015).

By late March, some weird - for lack of other words - rhetorical choices were used by Vučić, who at one time spoke that he was "collecting respirators like a beaver" (Mondo 2020), while some "secret agents" were also allegedly involved in procuring them (Direktno 2020). Interestingly, he additionally spoke negatively about Serbia's citizens who were returning to Serbia during the pandemic, accusing them of coming back "to get medical care for free" (Pešić 2020). The discourse then gradually became one of fearmongering and trying to scare one's audience into submission. Official addresses to the citizenry were almost exclusively either led by, or completely taken over by the President. Having in mind the scholarship on the issue, we realize that "within any 
given discourse, various actors seek to assert themselves and their pattern of argumentation and to establish a dominant discourse pattern" (Dunn Cavelty 2013:106); coupled with the fact that Vučić has been establishing dominance based on the "extrainstitutional accumulation of power" (Pavićević, in: Milanović Hrašovec 2016) for years, this can be said to have been expected.

After the news set in that the great hall of the Belgrade Fair was turned into an improvised hospital - a depressing image reminiscent of a large hospice - Vučić opined that he is "glad that the citizens are scared", adding that he would have to "think up something even worse" (Nedeljnik 2020b). A few days later, he spoke that he is "happy if he sometimes introduced unrest" (B92 2020). This can be, from a discourse analytical perspective, understood as a discourse of securitization, wherein "the enunciation of security itself creates a new social order wherein 'normal politics' is bracketed" (Balzacq 2005:171), and security itself becomes the focal point of rhetoric. As Vučić spoke, "not even the Lešće graveyard, or the Novo groblje graveyard, or the Central graveyard and the graveyard on Bežanijska kosa, will be enough to receive us all", should the elderly not listen to the advice to stay at home (Informer 2020c). The joke was by late March fully replaced by fearmongering. A telling timeline can be made by juxtaposing several statements by the epidemiologist in charge, Predrag Kon, where, from January to March, his statements changed from nonchalance to panic. On 26 January, he spoke that the "risk for Serbia is small, the coronavirus does not transmit rapidly" (Tanjug 2020); on February 26, he said that "the coronavirus is a disease that we can manage; on 14 March, he opined that he would "quit his job" if the schools should get closed due to the virus (Informer 2020d), while already on 21 March he spoke that "deathrates were not so large even with SARS" (Informer 2020a). The only difference between Vučić's underling and him is that the callousness, laughter, threats, and the like, were mostly reserved for the President.

\section{CONCLUSION}

Having in mind the track record of the Vučić regime, with all of its affairs, lack of professionalism, public spins and half-truths oft presented to the electorate, the discursive response to the novel coronavirus can said to have been expected. Serbia's government is nowadays well known to be almost entirely in the hands of Aleksandar Vučić, who seldom consults experts (placing loyal pundits instead of experts in positions of high rank), or even anybody, for that matter. Having surrounded himself by yes-men and ignorami, it is also expected that the initial view of the COVID-19 pandemic would not be a serious one. According to the psychologist, Radmila Vujić Bojović, "as everything here, so did the corona crisis see itself through a political prism, and this is an additional danger for us. Daily politics, calculations about holding the elections and political battles should today not be a topic. Here, political calculations and political interests are always a topic. And this is the largest risk we have. We have certainly lost three weeks from joking to making first radical measures" (Vulić Bojović, in: Drčelić 2020:22).

In summa, the official response of the government, as well as by the govern- 
ment-supporting media, was initially a jovial narrative wherein the novel coronavirus was presented as funny, a joke, coupled with conspiracy theories within the media, due to the increasingly lower and lower level of expertise within both the government and its media. After the gravity of the situation was finally been made clear, and after weeks of potential preventive measures have been lost, the narrative changed to one of danger. This danger was then presented by regular media conferences on which mostly Vučić spoke, together with PM Brnabić, Minister of Health Zlatibor Lončar, and longtime epidemiologist, Predrag Kon. Vučić's rhetoric changed to that of fearmongering, begging, imploring, and scolding. As preventive and curative measures have been taken, by the end of the writing of this article, the COVID-19 peak is yet to happen in Serbia.

It is important to stress the continuous following of the topic, not only through a discursive lens, but from the point of view of public health and policy as well. It is possible to argue that the more authoritarian the state is, or, at the least, the more authoritarian the leader is, the larger are the chance that initially, the virus would be misrepresented. Concomitantly, the chances of recovering from the pandemic will in all probability also be increased with an increase in state authoritarianism. As a semi-authoritarian state with a semi-authoritarian ruler, Serbia is not alone in misrepresenting the virus, but as well not alone in deploying drastic measures once the gravity of the pandemic set in. It is the paradox of authoritarianism that in cases such as a pandemic, the more authoritarian and repressive the measures, the greater chances of the pandemic wreaking havoc within the state.

FUNDING: This research received no external funding.

CONFLICT OF INTEREST: The author declares no conflict of interest.

\section{REFERENCES}

Alo. 2020. „”Nemojte Misliti Da Vas Napadam, Ali...”Voditeljka Pitala Vučića Za Spornu Konferenciju. Svima Kraj Malih Ekrana Zastao Dah Kada Su Čuli Odgovor.” Alo! Retrieved: 29 March 2020 (https://www.alo.rs/vesti/politika/korona-virus-aleksandar-vucic-jovana-joksimovic-emisija-vanredna-situacija-u-srbiji/299984/ vest).

Alo! 2017. „Potraga Za Atentatorom Na Vučića Muškarac Sa Fotografije Sipa Poznat Policiji!” Alo! Retrieved: 22 February 2018 (http://www.alo.rs/muskarac-sa-fotografije-sipa-poznat-policiji/91900).

Avakumović, Lana. 2020. „Još Loših Vesti Za Demokratiju U Srbiji.” Talas. Retrieved: 26 March 2020 (https://talas.rs/2020/03/25/jos-losih-vesti-za-demokratiju-u-srbiji/).

Aydın-Düzgit, Senem. 2016. "De-Europeanisation through Discourse: A Critical Discourse Analysis of Akp's Election Speeches." South European Society and Politics 21(1):45-58.

B92. 2020. „Vučić: U Roku Od 3 Do 4 Dana Odluka O Policijskom Času Od 24 
Sata.” B92. Retrieved: 30 March 2020 (https://www.b92.net/info/vesti/index. php? yyyy $=2020 \& m m=03 \& d d=29 \& n a v$ category $=12 \&$ nav id $=1670583$ ).

Balzacq, Thierry. 2005. "The Three Faces of Securitization: Political Agency, Audience and Context." European journal of international relations 11(2):171-201.

Beta. 2020. "Vučić: Izmišljena Afera O Umešanosti Oca Nebojše Stefanovića O Korupciji." Danas. Retrieved: 29 March 2020 (https://www.danas.rs/politika/vucic-izmisljena-afera-o-umesanosti-oca-nebojse-stefanovica-o-korupciji/).

Carvalho, Anabela. 2008. "Media(Ted) Discourse and Society: Rethinking the Framework of Critical Discourse Analysis.” Journalism studies 9(2):161-77.

Cicourel, Aaron V.1985. “Text and Discourse.” Annual Review of Anthropology 14(1):15985.

Danas. 2020. „Prvi Slučajevi Korone U Srbiji Registrovani Još 1. Marta, Ali Prećutani (Video)." Danas. (https://www.danas.rs/drustvo/prvi-slucajevi-korone-u-srbiii-registrovani-jos-1-marta-ali-precutani/).

Diamond, Dan. 2020. "Trump's Mismanagement Helped Fuel Coronavirus Crisis." Politico. Retrieved: 27 March 2020 (https://www.politico.com/news/2020/03/07/ trump-coronavirus-management-style-123465).

Direktno. 2020. “Smehom Protiv Vučićevih Fantazija." Direktno. Retrieved: 30 March 2020 (https://direktno.rs/politika/263026/smehom-protiv-vucicevih-fantazija-video.html).

Drčelić, Zora. 2020. „Kao Da Smrt Nije Ništa.” Vreme (1524). Retrieved: 28 March 2020. Dunn Cavelty, Myriam. 2013. "From Cyber-Bombs to Political Fallout: Threat Representations with an Impact in the Cyber-Security Discourse." International Studies Review 15(1):105-22.

Đurđević, Mila. 2019. «Afera Krušik: 〈Izmišljanje〉 Ili Prikrivanje.» Radio Free Europe. (https://www.slobodnaevropa.org/a/afera-krusik-izmisljanje-ili-prikrivanje/30228308.html).

FreedomHouse. 2016. "Serbia - Freedom of the Press.” Vol.: Freedom House.

Freedomhouse. 2019. “Serbia.” Vol.

Galasinski, Dariusz. 2000. The Language of Deception: A Discourse Analytical Study: Sage Publications.

Informer. 2016. "Spreman Atentat Na Vučića?! Nedaleko Od Porodične Kuće Premijera Pronađene Zolja, Ručne Bombe I Municija!” Informer. (http://informer.rs/ vesti/politika/297216/video-spreman-atentat-na-vucica-nedaleko-od-porodicne-kuce-premijera-pronadene-zolja-rucne-bombe-i-municija).

Informer. 2020a. „Ovako Brzo Se Nije Umiralo Ni Od Sarsa! Kon Ne Može Da Veruje Šta Se Dešava: Najveći Problem Je Što Mnogo Toga O Ovom Virusu Ne Znamo!” Informer. Retrieved: 31 March 2020 (https://informer.rs/vesti/drustvo/502091/ ovako-brzo-nije-umiralo-sarsa-kon-moze-veruje-sta-desava-najveci-problemsto-mnogo-toga-ovom-virusu-znamo).

Informer. 2020b. "Samo U Današnjem Informeru! Zahuktava Se Prljava Kampanja! Bolesni Plan Szs! Puštaju Laži O Koroni I Migrantima Da Odlože Izbore I Sruše Vučića!?” Informer:9 March 2020. (https://informer.rs/vesti/srbija/498722/samo-danasnjem-informeru-zahuktava-prljava-kampanja-bolesni-plan-szs-pus- 
taju-lazi-koroni-migrantima-odloze-izbore-sruse-vucica).

Informer. 2020c. „Neće Nam Biti Dovoljno Ni Novo Groblje, Ni Lešće, Ni Bežanija! Vučić: Penzioneri, Ne Slušajte Neodgovorne I Ne Izlazite Napolje - Vaši Životi Su U Pitanju!" Informer. Retrieved: 30 March 2020 (https://informer.rs/vesti/politika/503208/nece-nam-biti-dovolino-novo-groblje-lesce-bezanija-vucic-penzioneri-slusajte-neodgovorne-izlazite-napolje-vasi-zivoti-pitanju).

Informer. 2020d. „Ako Škole Budu Zatvorene Na Dve Nedelje, Podnosim Ostavku! Doktor Kon Objasnio Zašto Je Struka Protiv Prekida Nastave!” Informer. Retrieved: 31 March 2020 (https://informer.rs/vesti/drustvo/500090/ako-skole-budu-zatvorene-dve-nedelje-podnosim-ostavku-doktor-kon-objasnio-zasto-struka-protiv-prekida-nastave).

Jary, Mark. 2011. "Assertion, Relevance and the Declarative Mood." Procedural meaning: Problems and perspectives 25:267.

Jovanović, Srđan. 2018a. “'You're Simply the Best”: Communicating Power and Victimhood in Support of President Aleksandar Vučić in the Serbian Dailies Alo! And Informer." Journal of Media Research 11(2):22-42.

Jovanović, Srđan Mladenov. 2018b. “Poor Governance, Good Corruption: An Overview of Serbia’s Government's Affair-Ridden Governance (2012-2018).” Przegląd Europejski / The European Review 2018(4):161-78.

Jovanović, Srđan Mladenov. 2018c. "Headlines as Fake News: Discursive Deception in Serbia’s Daily “Informer'.” Central and Eastern European Review 12:1-22.

Jovanović, Srđan Mladenov. 2019. ““'One out of Five Million”: Serbia’s 2018-19 Protests against Dictatorship, the Media, and the Government's Response “. Open Political Science 2:1-8.

Leskovac, M and S Špero. 2015. "Najveći Pozer U Vladi Vulin Pustio U Rad Lift." Blic. Retrieved: 24 Nov 2016 (http://www.blic.rs/vesti/drustvo/najveci-pozer-u-vladivulin-pustio-u-rad-lift/my8mgj6).

Marić, N. 2020. "Epidemiolog Dr Branislav Tiodorović Otkriva Može Li Post Da Pomogne U Odbrani Od Koronavirusa?!” Alo! (https://www.alo.rs/vesti/drustvo/ evo-da-li-post-moze-da-pomogne-u-odbrani-od-koronavirusa/294066/vest).

Marković, Radmilo. 2020a. "Prećutali Prve Zaražene Zbog Prikupljanja Potpisa.” Nova. rs. (https://nova.rs/politika/precutali-prve-zarazene-zbog-prikupljanja-potpi$\underline{\mathrm{sa} /})$.

Marković, Radmilo. 2020b. “Zašto Nam Ne Verujete, Kada Vas Lažemo.” Vreme, 19 March 2020, pp. 16-19.

Milanović Hrašovec, Ivana. 2016. "Ne Zanima Me Politička Trgovina.” Vreme (1344). Retrieved: 30 March 2020 (https://www.vreme.com/cms/view.php?id=1433014).

Mondo. 2020. "Vučić: Skupljam Respiratore Kao Dabar, Neće Srbija Završiti Kao Njujork!” Mondo.rs. Retrieved: 29 March 2020 (https://mondo.rs/Info/Drustvo/ a1303431/Korona-virus-Aleksandar-Vucic-o-respiratorima.html).

N1. 2017. "Vulin: Hteo Sam U Uniformu, Ali Sam Imao Dioptriju Veću Od 7." N1. Retrieved: 28 March 2020 (http://rs.n1info.com/Vesti/a282170/Zasto-Vulin-nije-sluzio-Vojsku.html).

N1. 2019. "Afera "Krušik" - Vlast Izbegava Odgovore Na Pitanja, Institucije Ćute." 
N1. (http://rs.n1info.com/documents/1393134/comments/Vesti/Afera-Krusik-vlast-izbegava-odgovore-na-pitanja-institucije-cute.html).

Nedeljnik. 2020a. “Kisić Tepavčević: Napravila Sam Lapsus. Prvi Slučaj Koronavirusa U Srbiji Zabeležen Je 6. Marta.” Nedeljnik. (https://www.nedeljnik.rs/kisic-tepavcevic-napravila-sam-lapsus-prvi-slucaj-koronavirusa-u-srbiji-zabelezen-je-6-marta/?utm_medium=Social \&utm_source=Facebook\&\&\#Echobox $=1584974014$ ).

Nedeljnik. 2020b. „Vučić: Moraću Da Smislim Nešto Gore Od Sajma, Drago Mi Je Što Se Građani Plaše.” Nedeljnik. Retrieved: 30 March 2020 (https://www.nedeljnik.rs/ vucic-moracu-da-smislim-nesto-gore-od-sajma-drago-mi-je-sto-se-gradaniplase $/$ ).

Ottaway, Marina. 2013. Democracy Challenged: The Rise of Semi-Authoritarianism: Carnegie Endowment.

Parodi, Emilio, Silvia Aloisi and Pamela Barbaglia. 202. "Special Report: 'All Is Well'. In Italy, Triage and Lies forVirus Patients.” Reuters. Retrieved:25 March 2020 (https:// www.reuters.com/article/us-health-coronavirus-italy-ethics-speci/special-report-all-is-well-in-italy-triage-and-lies-for-virus-patients-idUSKBN2133KG).

Paton, Stephen. 2020. “Boris Johnson Makes 'Last Gasp’ Joke About Lack of Ventilators Amid Pandemic.” The National. Retrieved: 27 March 2020 (https://www.thenational.scot/news/18310479.boris-johnson-makes-last-gasp-joke-lack-ventilators-amid-pandemic $/$ ).

Pešić, Vesna. 2020. “Zaključana Vrata Države.” Peščanik. Retrieved: 29 March 2020 (https://pescanik.net/zakljucana-vrata-drzave).

Phillips, Tom. 2020. “Bolsonaro Says He 'Wouldn't Feel Anything' If Infected with Covid-19 and Attacks State Lockdowns.” The Guardian. Retrieved: 27 March 2020 (https://www.theguardian.com/world/2020/mar/25/bolsonaro-brazil-wouldntfeel-anything-covid-19-attack-state-lockdowns).

Popović, Predrag. 2017. "Velika Afera Trese Srbiju: Vučićev Ministar Zvani “Doktor Smrt” Likvidirao Protivnike Zemunskog Kriminalnog Klana?!” 6yka. Retrieved: 22 January 2019.

Puzynina, Janina. 1992."Jezyk W Swiecie Wartosci (Language in the World of Values).” Warsaw: Panstwowe Wydawnictwo Naukowe.

Radeljić, Branislav. 2019. "Tolerating Semi-Authoritarianism? Contextualising the Eu's Relationship with Serbia and Kosovo.” Pp. 157-80 in The Europeanisation of the Western Balkans: Springer.

Rujević, Nemanja. 2017. "Stilske Vežbe Aleksandra Vučića." Deutsche Welle. Retrieved: 28 March 2020 (https://www.dw.com/sr/stilske-ve\%C5\%BEbe-aleksandra-vu\%C 4\%8Di\%C4\%87a/a-41256933).

Rumelhart, David E, Donald A Norman and John R Anderson. 1981. "Analogical Processes in Learning." Cognitive skills and their acquisition:335-59.

Tanjug. 2015. "Vučić: Ne Dam Gašića I Lončara.” B92. Retrieved: 29 March 2020 (https://www.b92.net/info/vesti/index.php?yyyy $=2015 \& \mathrm{~mm}=03 \& \mathrm{dd}=16 \&$ nav category=11\&nav id=969237).

Tanjug. 2020. „Kon: Rizik Za Srbiju Je Mali, Koronavirus Se Ne Prenosi Ubrzano.” Blic. 
Retrieved: 31 March 2020 (https://www.blic.rs/vesti/drustvo/kon-rizik-za-srbiju-je-mali-koronavirus-se-ne-prenosi-ubrzano/3j0bc2d).

Telesković, Dušan. 2019. „Afera U “Krušiku”: (U)Zbunjivanje Pravde.” Nedeljnik. (https://www.nedelinik.rs/afera-u-krusiku-uzbunjivanje-pravde/).

TV, Link. 2019. „Zdravo Sa Profesorom Nestorovićem - Plavooki Su Vanzemaljci Epizoda 36.” Retrieved 25 March 20120 (https://www.youtube.com/watch?v=GWqTGoIU4Po).

Wang, Junling. 2010. “A Critical Discourse Analysis of Barack Obama's Speeches.” Journal of language teaching and research 1(3):254-61.

\section{BIOGRAPHICAL NOTE}

Srđan Mladenov Jovanović is an interdisciplinary historian and political scientist, living and working in Tianjin, China, as an Associate Professor at the College of History, Nankai University. Prior to moving to China, he taught and/or conducted research at Lund University (Sweden), the Polish Academy of Sciences' Institute for Advanced Study (Poland), Palacky University Olomouc (Czech Republic), University of Košice (Slovakia), New Europe College (Romania), and Istanbul Sehir University (Turkey). He is the author of a number of research articles and several books, as well as the holder of numerous fellowships on an international levels. He speaks English, Serbo-Croatian, Czech, and Swedish, with working knowledge of Russian, German, Polish, Slovak, Italian, and Mandarin.

OPEN ACCESS: This article is distributed under the terms of the Creative Commons Attribution Non-commercial License (CC BY-NC 4.0) which permits any non-commercial use, and reproduction in any medium, provided the original author(s) and source are credited.

ARTICLE HISTORY: Received 2020-03-30 / Accepted 2020-04-06 